Однако, представляется, что данного содержания договор, вполне вероятно, не будет удостоверен нотариусом, так как данное его условие попадает под определение постановки одно из супругов в «крайне неблагоприятное» положение. А на нотариуса в свою очередь возлагается обязанность проверки содержания брачного договора на соответствие его содержания закону.

Представляется, что российской законодательство, регламентирующее брачнодоговорные отношения, в настоящий момент достаточно развито и не позволяет недобросовестному супругу избежать имущественной ответственности посредством заключения брачного договора: соглашение с подобным условием либо не будет удостоверено нотариусом изначально, или же суд, возможно, признает его недействительным.

1. Семейный кодекс Российской Федерации от 29 декабря 1995 г. N 223-Ф3 // Собрание законодательства Российской Федерации. 1996 г. N 1 ст. 16

2. Постановление Пленума Верховного Суда РФ от $05.11 .1998 \mathrm{~N} 15$ «О применении судами законодательства при рассмотрении дел о расторжении брака» // СПС КонсультантПлюс

3. Волченкова Т.П. Брачный договор в России: сущность и проблемы применения // Вопросы науки и образования. 2017. 2 с.

4. Захарова С.Н. Брачный договор: понятие и его заключение // Научный журнал. 2019. 3 с.

5. Иванова Н.А. Брачный договор как способ защиты имущественных прав супругов // Вестник Тамбовского университета. Серия: Политические науки и право. 2015.9 с.

6. Шумова К.А., Сидорова С.В. Брачный договор: основные аспекты, признание недействительным договора в суде // Бюллетень науки и практики. 2020. Т. 6. № 8. С. 222-225

\title{
Гутник И.С., Мамин А.С. \\ Цели и задачи органов внутренних дел в сфере реализации государственной политики противодействия экстремизму
}

Белгородский государственньй национальный исследовательский университет doi: $10.18411 / \mathrm{j}-05-2021-172$

(Россия, Белгород)

\section{Аннотация}

Данная статья направлена на рассмотрение целей и задач государственной политики противодействия экстремизму. Авторы выделяют приоритетные цели, а также выделяют задачи противодействия экстремизму, реализующих органами внутренних дел и проводят их анализ.

Ключевые слова: органы внутренних дел, государственная политика, противодействие экстремизму.

\section{Abstract}

This article is aimed at considering the goals and objectives of the state policy of countering extremism. The authors identify priority goals, as well as identify the tasks of countering extremism implemented by the internal affairs bodies and analyze them.

Keywords: internal affairs bodies, state policy, countering extremism.

Государственная политика в сфере противодействия экстремизму определяет своими главными целями защиту основ конституционного строя российского государства, прав и свобод граждан от экстремистских угроз, а также общественной безопасности. Данные цели осуществляются на федеральном, региональном, муниципальном уровнях с помощью определенных действий организационного, а также правового характера, которые вырабатываются на основе изучения результатов в области противодействия экстремизму. 
Обозначенные выше цели обуславливаются следующими задачами:

- совершенствование действующего законодательства и правоприменительной практики в данной области;

- интеграция усилий федеральных органов государственной власти, органов государственной власти субъектов Российской Федерации, а также органов местного самоуправления и иных институтов в целях противодействия любых проявлений экстремизма;

- разработка и организация в средствах массовой информации, а также в сети «Интернет» медийного сопровождения деятельности федеральных органов государственной власти, органов государственной власти субъектов РФ, а также органов местного самоуправления, реализация мер информационного противодействия распространению идеологии экстремизма;

- разработка, внедрение и реализация комплексных мер повышения профилактики, выявления, а также преступления правонарушений и преступлений в области экстремизма.

Говоря о структуре субъектов, осуществляющих данную политику, необходимо отметить, что центральным элементом в такой структуре являются органы внутренних дел. На данную систему органов возложен ряд задач и обязанностей, реализация которых составляет основополагающую составляющую антиэкстремистской деятельности на всех уровнях ее осуществления.

К основным задачам, возложенным на органы внутренних дел в данной области относятся информационно-аналитические, оперативно-профилактические; оперативнорозыскные; охранно-защитные; организационные; информационно-пропагандистские; уголовно-процессуальные.

К информационно-аналитическим задачам, в первую очередь, относится:

- выявление и определение лиц, совершающих подготовку, совершающих и совершивших преступления, связанные с экстремизмом, а именно сбор, обобщение и анализ оперативной информации о лицах, причастных к каким-либо экстремистским действиям.

- анализирование информации о физических лицах, организаций, попадают под подозрение в финансировании экстремистских организаций;

- реализация международного розыска определенных лиц, организаций, подозреваемых в совершении преступлений в области экстремистской деятельности;

- реализация комплекса мер оперативно-профилактического характера по противодействию экстремизму;

- анализ деятельности органов внутренних дел по обеспечению правопорядка на территории российского государства, внесение предложений, рекомендаций в органы внутренних дел Российской Федерации по совершенствованию обеспечения общественного порядка, общественного порядка, a также борьбы с экстремистскими проявлениями;

- разработка и организация специального профессионального обучения, повышение квалификационных знаний, навыков, умений, а также профессиональной подготовки, переподготовки сотрудников подразделений по противодействию экстремизму.

К оперативно- профилактическим следует отнести следующие:

- организация и реализация оперативно-розыскных, а также профилактических мероприятий по выявлению, предупреждению, 
пресечению, раскрытию преступлений, а также правонарушений, связанных с экстремистскими проявлениями;

- выработка мер по предупреждению, выявлению, а также пресечению фактов содействия со стороны сотрудников, федеральных государственных служащих, лицам, которые подготавливают, а также совершают преступления, связанные с экстремистской деятельностью;

- выработка мер по предотвращению проникновения на службу в органы внутренних дел тех лиц, которые участвуют в экстремистской деятельности.

К оперативно- розыскным как правило относят:

- розыск подозреваемых граждан, а также лиц, которые привлечены к уголовной ответственности за преступления, связанные с экстремистской деятельностью, а также скрывшихся от органов исполнительной власти или суда;

- выработка и проведение специальных операций по перекрытию каналов поставки физическим лицам и организациям экстремистских материалов и др.

Охранно- защитные включают в себя:

- организацию мероприятий по обеспечению безопасности объектов в целях предупреждения и пресечения подготовки и совершения на них преступных деяний, связанных с экстремистской деятельностью, находящихся под охраной под охраной подразделений вневедомственной охраны;

— обеспечение гарантий государственной защиты жизни, здоровья, и имущества сотрудников органов внутренних дел, а также их семей;

- разработка и применение мер безопасности, необходимых для защиты жизни, здоровья лиц, подлежащих государственной защите, в ходе уголовного судопроизводства по делам, связанных с экстремистской деятельностью и др.

К организационным задачам следует отнести следующие:

- выработка и организация мер по взаимодействию с органами исполнительной власти субъектов РФ и органами местного самоуправления по профилактике правонарушений, связанных с экстремистской деятельностью;

- выработка и организация мер по сотрудничеству с работниками частных охранных и сыскных организаций, а также служб безопасности, в целях предупреждения преступлений и правонарушений, связанных с экстремистской деятельностью в области транспортной инфраструктуры.

К информационно-пропагандистским задачам относятся следующие:

- организация и проведение информационно-пропагандистских мероприятий в сфере противодействия экстремизму;

- организация и проведение информационно- пропагандистских мероприятий по противодействию распространения идей экстремизма;

- оповещение соответствующих органов государственной власти РФ, органов местного самоуправления, а также общественные объединения о текущем состоянии и результатах противодействия экстремизму.

Уголовно- процессуальные задачи включают в себя следующие:

— выработка и организация деятельности подчиненных подразделений по качественному и полному расследованию преступлений, связанных с экстремистской деятельностью, находящихся в производстве, 
выявлении в процессе расследования причин и условий, способствующих их совершению и принятию, мер к их устранению;

- взаимодействие с органами прокуратуры и судами при расследовании уголовных дел по преступлениям экстремистской направленности.

Итак, при рассмотрении целей и задач реализации органами внутренних дел государственной политики в области противодействия экстремизму, стоит отметить, что перечень задач, является достаточно широким и исчерпывающим, однако в нем полностью проигнорированы задачи административно-правового воздействия, которые являются действенным инструментом профилактики, a также борьбы с экстремистскими правонарушениями.

Таким образом, авторы считают необходимым разработать и внести указанные задачи в сформированный перечень. Для полноценного и эффективного применения данных задач в борьбе с правонарушениями и преступлений в области преступлений, связанных с экстремистской деятельностью следует возложить основные функции по реализации таких задач на Главное управление противодействию экстремизму Российской Федерации.

\section{$* * *$}

1. Конституция Российской Федерации (принята всенародным голосованием 12.12.1993 с изменениями, одобренными в ходе общероссийского голосования 01.07.2020) // Официальный интернет-портал правовой информации. - URL: http://www.pravo.gov.ru. (дата обращения:15.04.2021).

2. О противодействии экстремистской деятельности: Федеральный закон от 25.07.2002 № 114-Ф3 (ред. от 08.12.2020) // Собрание законодательства РФ. - 29.07.2002. № 30. ст. 3031.

3. Об утверждении Стратегии противодействия экстремизму в Российской Федерации до 2025 года: Указ Президента РФ от 29.05.2020 № 344 // Собрание законодательства РФ. - 01.06.2020. - № 22. ст. 3475.

4. Авдеев, В.А. Механизм противодействия преступлениям террористического характера и экстремистской направленности в Российской Федерации / В.А. Авдеев, О.А. Авдеева // Юридический мир. - 2014. - № 12. - С. 59-63.

5. Актуальные проблемы взаимодействия органов государственной власти и местного самоуправления с религиозными организациями и вопросы противодействия религиозному экстремизму: материалы семинара. - Тюмень, 2014.

\section{Далгалы Т.А., Матвеева П.М. \\ Типология личности преступника в Российской Федерации}

Красноярский государственный аграрный университет (Россия, Красноярск)

doi: $10.18411 / \mathrm{lj}-05-2021-173$

\section{Аннотация}

Дано определение типологии личности преступника. Исследованы типологические черты личности преступника, проведен криминологический анализ личности преступника с точки зрения социально - психологических критериев. А также уделено внимание факторам, способствующим формированию личности преступника.

Ключевые слова: личность преступника, статья, квалификация преступления, типология преступников.

\section{Abstract}

The definition of the typology of the personality of the offender The typological traits of the criminal's personality are investigated, the criminological analysis of the criminal's personality from the point of view of social and psychological criteria is carried out. And also attention is paid to the factors contributing to the formation of the personality of the offender. criminals.

Key words: identity of the offender, article, qualification of the crime, typology of 